\title{
MENINGKATKAN MOTIVASI BELAJAR MENGGUNAKAN MEDIA PEMBELAJARAN METODE SYDW PADA PELAJARAN MATEMATIKA DI SMPN 3 PAREPARE
}

\author{
Edy Sofyan ${ }^{1}$, Gusniwati, ${ }^{2}$ Buhaerah $^{3}$ \\ ${ }^{1}$ Mahasiswa Institut Agama Islam Negeri (IAIN) Parepare, Jln. Amal Bakti, Parepare 91132, Indonesia \\ 2 Dosen Institut Agama Islam Negeri (IAIN) Parepare, Jln. Amal Bakti, Parepare 91132, Indonesia \\ ${ }^{3}$ Dosen Institut Agama Islam Negeri (IAIN) Parepare, Jln. Amal Bakti, Parepare 91132, Indonesia \\ Email : edysofyan@iainpare.ac.id \\ Email : gusniwati@iainpare.ac.id \\ Email : buhaerahstain@gmail.com
}

\begin{abstract}
Abstrak: Pemanfaatan dan sosialisasi video instruksional adalah solusi efektif untuk pembelajaran online selama pandemi Covid-19. Video pembelajaran ini berbantuan aplikasi YouTube dan WhatsApp. Penggunaan aplikasi ini dapat membantu siswa berpartisipasi dalam kegiatan selama pandemi Covid-19.Selain itu, aplikasi YouTube dan WhatsApp juga dapat memberikan inovasi bagi guru untuk mengembangkan media pembelajaran online. Metode yang digunakan adalah SYDW (Sharing to Youtube and Discussion in WhatsApp ). Kegiatan ini dilaksanakan di UPTD SMPN 3 Parepare, Kecamatan Bacukiki Barat,Kelurahan Bumi Harapan, Kota Parepare, Provinsi Sulawesi Selatan. Kegiatan ini melibatkan siswa SMP kelas IX.1. Hasil survei menunjukkan bahwa melalui penggunaan video pembelajaran berbasis YouTube dan WhatsApp, sebagian besar siswa dapat memahami materi dengan baik. Dengan video pembelajaran, siswa juga termotivasi untuk belajar. Selain itu, belajar juga menjadi menyenangkan dan menarik sehingga video pembelajaran dapat menjadi alternatif dalam mengatasi kesulitan belajar siswa di tengah pandemi Covid-19. Video pembelajaran tersebut dapat membantu guru menyampaikan pelajaran dengan baik dan jelas sehingga siswa lebih mudah memahami pelajaran karena adanya penjelasan dari guru yang mereka lihat melalui video pembelajaran. Dengan demikian, dapat disimpulkan bahwa video pembelajaran berbasis aplikasi YouTube dan WhatsApp adalah solusi ketersediaan sumber belajar siswa yang variatif dan menjadi inovasi pembelajaran bagi guru.
\end{abstract}

Kata Kunci: Metode SYDW; media pembelajaran, pandemi covid-19

\begin{abstract}
The utilization and socialization of instructional videos is an effective solution for online learning during the Covid-19 pandemic. This learning video is based on the YouTube and WhatsAppapps. The use of this application can help students participate in activities during the Covid-19 pandemic. In addition, the YouTube and WhatsApp applications can also provide innovation for teachers to develop online learning media. The method used is SYDW (Sharing to Youtube and Discussion in WhatsApp). This activity was held at UPTD SMPN 3 Parepare, West BacukikiSubdistrict, Bumi Harapan Village, Parepare City, South SulawesiProvince. This activity involves students of SMP class IX.1. The survey results showed that through the use of YouTube and WhatsApp-based learning videos, most students were able to understand the materialwell. With learning videos, students are notermotivated to learn. In addition, learning also becomes fun and interesting sothat learning videos can be an alternative in overcoming students' learning difficulties in the midst of the Covid-19 pandemic. The learning video can help teachers convey lessons well and clearly sothat students more easily understand thelesson because of the explanation from the teacher they see through the learning video. Thus, it can be concluded that YouTube and WhatsApp-based learning videos can be used as a source of learning for students and as a learning innovation for teachers.
\end{abstract}

Keywords: SYDW Method; learning media, pandemic covid-19

Pi: Mathematics Education Journal 


\section{Pendahuluan}

Pemanfaatan dan sosialisasi video instruksional adalah solusi efektif untuk pembelajaran online selama pandemi Covid-19. Video pembelajaran ini menggunakan aplikasi YouTube dan WhatsApp. Video pembelajaran merupakan media yang menampilkan audio dan visual kegiatan pembelajaran berupa konsep yang memberikan pemahaman pembelajaran .Video pembelajaran dijadikan sebagai sumber belajar bagi siswa sehingga dapat membantusiswamengatasikesulitan dalam belajar. Selain itu, video pembelajaran dari YouTube juga dapat membantu guru dalam membuat video pembelajaran bagi siswanya dengan kreatif . Namun, video pembelajaran masih belum dimanfaatkan dalam pembelajaran di provinsi Sulawesi Selatan, terkhususnya UPTD SMPN 3 Parepare, Kecamatan Bacukiki Barat,Kelurahan Bumi Harapan, Kota Parepare. Kegiatan ini melibatkan siswa SMP kelas IX.1.

Berdasarkan hasil survei, siswa yang mengalami kesulitan dalam belajar masih banyak. Survei dilakukan terhadap 30 orang siswa kelas XI.1 SMP melalui angket secara online. Dari 30 orang siswa tersebut, 21 orang mengalami kesulitan saat belajar online (daring). Beberapa faktor yang menyebabkan siswa kesulitan dalam belajar adalah (1) tidak adanya penjelasan materi dari guru sehingga siswa harus belajar sendiri; (2) kurangnya minat belajar karena belajar menjadi membosankan; (3) Tidak ada yang bisa bertanya apakah ada pelajaran yang tidak bisa dipahami; dan (4) Tidak ada kuota internet untuk mencari video pembahasan materi pelajaran. Oleh karena itu dalam menghadapi kesulitan, siswa menjadi malas belajar.

Sumber belajar yang digunakan siswa tidak difasilitasi. Berikut hasil survei tentang sumber belajar siswa saat belajar di rumah.

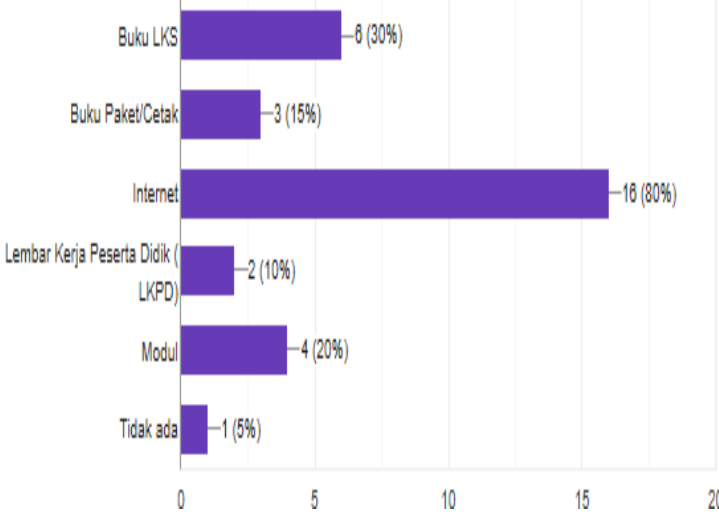

Terlihat dari grafik bahwa sebagian besar mahasiswa hanya mengandalkan internet untuk mencari informasi / materi belajarnya. Sedangkan, sangat sedikit siswa yang menggunakan buku, Lembar Kerja Peserta Didik (LKPD), dan modul sebagai sumber belajar sehingga dapat dikatakan sumber belajar siswa masih terbatas akibatnya siswa mengalami kesulitan dalam memahami pelajaran maupun mengerjakan tugas. Oleh karena itu, anak-anak mungkin merasa terbebani dengan tugas-tugas yang mungkin tidak mereka pahami tanpa adanya bimbingan dari guru.

\section{Metode Penelitian}

Penelitian menggunakan metode studi kasus deskriptif kualitatif, yaitu sebatas gambaran mengenai fakta dan rangsangan sistemik serta peristiwa yang berkaitan dengan hubungan antara faktor, ciri dan fenomena, yang hanya dilakukan untuk operasi dasar. Penelitian ini menyediakan data deskriptif dan perilaku yang akan diamati baik secara tertulis maupun verbal. Data yang dikumpulkan berupa kalimat dan penjabaran jawaban dari subjek yang dilakukan dengan wawancara siswa. Pengambilan subjek dengan metode survey. Subjek penelitian adalah siswa kelas IX.1 SMPN 3 parepare. Jawaban dari subjek merupakan deskripsi dan saran dari pengaruh Covid19 terhadap proses pembelajaran 
matematika di UPTD SMPN 3 Parepare. Data tersebut dideskripsikan secara kualitatif.

\section{Hasil Penelitian Dan Pembahasan}

Menurut (Surya, 2017:14) ilmu pengetahuan dan teknologi didukung pembelajaran matematika akan tetapi siswa masih menganggap matematika suatu pelajaran yang sulit dan tidak menyenangkan. Kami menemukan bahwa siswa kurang minat dalam matematika dalam pembelajaran langsung. Pada saat inilah kreativitas guru ditingkatkan. Guru hendaknya menghasilkan media pembelajaran alternatif untuk membantu siswa belajar daring. Namun, hal ini tidak seutuhnya terlaksana.

Pembelajaran daring tidaklah berbeda dengan pembelajaran luring, guru memberikan tugas kepada siswa untuk dikerjakan akan tetapi pemberian tugas oleh guru hendaknya memperhatikan kondisi siswa apakah mungkin diberikan tugas tanpa memberi materi saat pembelajaran daring.

Siswa dan guru dapat berinteraksi secara daring melalui aplikasi yaitu khususnya YouTube dan WhatsApp yang dapat membantu kegiatan belajarmengajar jarak jauh (online) pada masa pandemic. Pembelajaran tersebut adalah sebuah inovasi pendidikan dalam

menjawab tantangan dalam hal ketersediannya sumber belajar yang bervariatif.

Agar 30 siswa menanggapi video pembelajaran tersebut, kami melakukan survei kuesioner (formulir Google) melalui WhatsApp. Angket ini bertujuan untuk melihat respon siswa tentang belajar menggunakan video pembelajaran dengan begitu, dapat diketahui apakah video pembelajaran dapat membantu siswa dalam belajar atau tidak. Berikut angket yang diberikan kepada siswa.

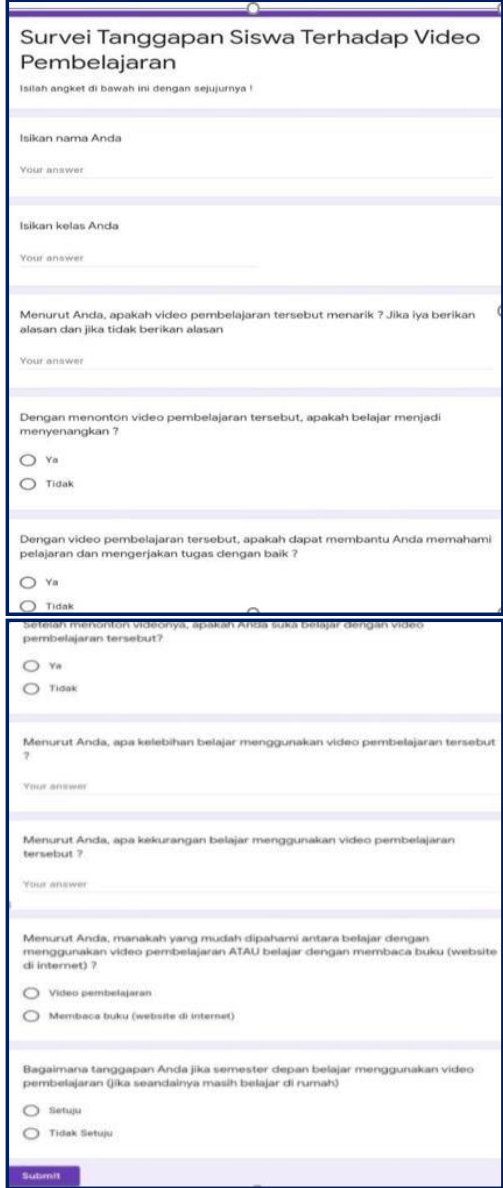

Gambar 1. Angket Evaluasi

Berdasarkan hasil survei yang telah dilakukan, siswa lebih mampu memahami pelajaran dengan menggunakan video pembelajaran. Di antara 30 siswa, $85 \%$ dapat menggunakan video instruksional untuk memahami konten belajar dan menyelesaikan tugas dengan baik. Jadi, dapat dilihat peningkatan kepahaman dan motivasi belajar siswa jauh lebih baik menggunakan video pembelajaran dibandingkan hanya sekedar membagikan tugas langsung melalui aplikasi WhatsApp saja.

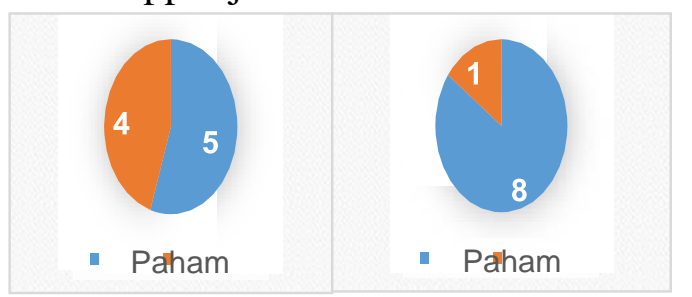

Gambar 2. (a) Persentase Tingkat Kepahaman Siswa Terhadap

Pi: Mathematics Education Journal 
Pelajaran Sebelum Diberikan Video Pembelajaran (b) Persentase Tingkat Kepahaman Siswa Terhadap Pelajaran Sesudah Diberikan Video Pembelajaran

Selain itu, reaksi siswa terhadap video pembelajaran juga sangat baik karena menyenangkan, animasi atau gambar yang menarik. Melalui video pembelajaran, siswa dapat lebih mudah mempelajari mata pelajaran. Hal ini disebabkan karena adanya penjelasan yang jelas dan rinci dari guru. Siswa juga dapat melihat (membaca) sekaligus mendengarkan penjelasan dari guru sehingga dapat dikatakan, kedua organ yaitu telinga dan mata difungsikan untuk menonton video. Itulah yang membuat siswa lebih mudah memahami pelajaran. Selain itu, siswa juga mudah mengingat pelajaran. Video pembelajaran dapat diulang-ulang. Oleh karena itu, jika siswa tidak yakin, siswa dapat mengulang dan mendiskusikan video tersebut di grup WhatsApp dengan kata lain menggunakan metode SYDW (Sharing to Youtube and Discussion in WhatsApp). Jadi dapat disimpulkan bahwa, video pembelajaran dapat membantu siswa belajar dari rumah. Apalagi di zaman sekarang ini,

semua kehidupan tidak lepas dari smartphone, baik untuk bermain game, mengakses media sosial, mencari informasi, dan sebagainya. Momen ini bisa dijadikan kesempatan untuk memanfaatkan video pembelajaran di tengah pembelajaran online. Video pembelajaran dapat ditonton melalui smartphone siswa. Siswa bisa menonton video tersebut sambil tetap menggunakan smartphone-nya. Bahkan, mereka bisa menggunakan ponsel cerdas mereka untuk menonton video di antara aktivitas lain. Selain itu, video pembelajaran memiliki animasi, suara, dan gambar yang menarik sehingga juga membuat siswa tertarik untuk belajar. Pembelajaran pun juga menjadi menyenangkan dengan video pembelajaran.

Begitu juga dengan guru yang memberikan respon positif terhadap video pembelajaran. Menurut wawancara dengan guru matematika, guru terinspirasi untuk menggunakan video dalam pelajaran mereka. Guru mengatakan bahwa video pembelajaran memberikan solusi untuk pembelajaran online selama masa pandemi Covid-19. Melalui video instruksional, guru dapat memberikan instruksi yang jelas dan rinci untuk materi tersebut sehingga siswa tidak bingung dan mampu memahami pelajaran dengan baik. Selain itu, siswa juga berminat dan termotivasi untuk belajar. Oleh karena itu, melalui video pembelajaran, kecemasan guru terhadap siswa yang kurang memahami pelajaran ini dapat dihilangkan. Walaupun tidak seperti tatap muka yang adanya interaksi dua arah, dimana siswa juga dapat bertanya kepada gurunya jika kurang paham. Akan tetapi, dengan video pembelajaran setidaknya siswa sudah mendengar dan melihat penjelasan dari guru secara langsung. Jadi dapat disimpulkan bahwa, dengan video pembelajaran guru bisa yakin dapat membantu siswa dalam meningkatkan motivasi dan semangat belajar dalam memahami pelajaran.

\section{Kesimpulan}

Berdasarkan pembahasan di atas, maka dapat disimpulkan bahwa video pembelajaran berbasis YouTube dan WhatsApp dapat membantu siswa dan guru khususnya di SMP NEGERI 3 parepare di tengah pembelajan online. Video pembelajaran menjadi sumber belajar bagi siswa, atau sebagai solusi dan inovasi pembelajaran online dimasa pandemi. Video pembelajaran tersebut membuat siswa bersemangat untuk belajar. Belajar menjadi menyenangkan karena adanya animasi atau gambar yang 
menarik sehingga memudahkan siswa dalam memahami pelajaran. Selain itu, video pembelajaran juga membantu guru dalam menyampaikan materi pelajaran sehingga video pembelajaran tersebut dapat dijadikan media dalam belajar online di tengah pandemi Covid-19, dengan begitu kesulitan guru di tengah pembelajaran online (daring) dapat lebih mudah dalam memberikan pemahaman kepada siswa.

\section{Referensi}

Alami, Y. (2020). Media Pembelajaran Daring pada Masa Covid19. Tarbiyatu Wa Ta'lim: Jurnal Pendidikan Agama Islam,2(1), 4956. Retrieved from https://ejournal.staisyamsululum.ac.i d/index.php/jtt/article/view/71

Amal, B. K. (2019). Pembelajaran Blended Learning Melalui Whatsapp Group (Wag). Retrieved from http://digilib.unimed.ac.id/id/eprint/3 7292

Aslam, A. F. F. Pemanfaatan Sumber Belajar Dalam Pembelajaran Online Pada Masa Pandemi Covid-19. Retrieved from https://www.academia.edu/download /63965375/Artikel_Andi_Fahdilah_F itriani_Aslam20200719-224788wzhuj.pdf

Astuti, A. (2021). Whatsapp dalam Pembelajaran Online Dimasa Pandemi Covid 19 di MTs Alhutsaimin pada Mata Pelajaran Matematika. Jurnal Pendidikan Tambusai, 5(1), 10-16. Retrieved from https://www.jptam.org/index.php/jpt am/article/view/1028

Kamhar, M. Y., \& Lestari, E. (2019). Pemanfaat Sosial Media Youtube Sebagai Media Pembelajaran Bahasa
Indonesia DI Perguruan

Tinggi. Inteligensi: Jurnal Ilmu Pendidikan, 1(2), 1-7. Retrieved from https://jurnal.unitri.ac.id/index.php/in teligensi/article/view/1356

Lasabuda, N. E. (2018). Pengembangan Media Youtube Dalam Pembelajaran Matematika (Suatu Penelitian Di Smk Kesehatan Bakti Nusantara Gorontalo). Jurnal Pascasarjana, 2(2), 270-275. Retrieved from http://ejurnal.pps.ung.ac.id/index.php /JPS/article/view/145

Pangarsa, A. A. T. (2020). Implementasi Media Video Youtube dalam Pembelajaran PPKn untuk Meningkatkan Motivasi Belajar Siswa Kelas VI MI Miftahul Abror. MODELING: Jurnal Program Studi PGMI, 7(2), 154-166. Retrieved from http://www.jurnal.stitnualhikmah.ac.i $\mathrm{d} /$ index.php/modeling/article/view/6 63

Prajana, A. (2017). Pemanfaatan aplikasi whatsapp untuk media pembelajaran dalam lingkungan uin ar-raniry Banda Aceh. Cyberspace: Jurnal Pendidikan Teknologi Informasi, 1(2), 122-133.

Sari, N., \& Surya, E. (2017). Analysis effectiveness of using problem posing model in mathematical learning. International Journal of Sciences: Basic and Applied Research (IJSBAR), 33(3), 13-21. Retrieved from https://core.ac.uk/download/pdf/2493 35822.pdf

Setiawati, G. A. D., \& Ekayanti, N. W. (2020). Potret Pembelajaran Menggunakan Whatsapp, Google Classroom, Dan Youtube Di Masa Pandemi Covid-19. Prosiding Webinar Nasional Universitas Mahasaraswati Denpasar 2020, 225- 
230

Retrieved

from

http://ejournal.unmas.ac.id/index.php

/webinaradat/article/view/1217 